\title{
Pengaruh Pemberian Diet Tinggi Minyak Sawit terhadap Kadar Trigliserida Darah pada Tikus Wistar
}

\author{
Aufa Azri Dany ${ }^{1}$, Susila Sastri ${ }^{2}$, Eliza Anas ${ }^{3}$
}

\begin{abstract}
Abstrak
Minyak sawit merupakan salah satu minyak yang paling banyak dikonsumsi di Indonesia. Minyak sawit diketahui mengandung kurang lebih 50\% asam lemak jenuh dan 50\% asam lemak tidak jenuh. Penelitian sebelumnya menemukan bahwa mengonsumsi minyak sawit dengan dosis tertentu dapat mempengaruhi kadar trigliserida darah. Tujuan penelitian ini adalah menentukan pengaruh pemberian diet tinggi minyak sawit terhadap kadar trigliserida darah tikus wistar. Penelitian ini merupakan studi eksperimental dengan menggunakan post test only control group design. Sampel terdiri dari 12 ekor tikus wistar jantan yang dibagi menjadi dua kelompok, yaitu kelompok tikus kontrol yang diberi diet standar dan kelompok tikus perlakuan yang diberi tambahan 42,5\% minyak sawit ke dalam diet standar. Pemeriksaan kadar trigliserida setelah perlakuan empat minggu. Hasil penelitian menunjukkan bahwa pemberian diet timggi minyak sawit berpengaruh terhadap peningkatan kadar trigliserida darah. Rerata kadar trigliserida darah pada kelompok perlakuan adalah $165.6 \pm 19.527 \mathrm{mg} / \mathrm{dl}$ dan kelompok kontrol adalah $100.8 \pm 18.033 \mathrm{mg} / \mathrm{dl}$. Terdapat perbedaan bermakna antara kadar trigliserida darah pada kelompok perlakuan dibandingkan dengan kelompok kontrol $(p<0,05)$. Kesimpulan hasil penelitian ini adalah diet tinggi minyak sawit dapat meningkatkan kadar triliserida darah.
\end{abstract}

Kata kunci: minyak sawit, trigliserida darah

\section{Abstract}

Palm oil is one of the most widely consumed in Indonesia. Palm oil contain of 50\% saturated fatty acid and 50 $\%$ non saturated fatty acid. Previous studies have found that palm oil consumption in certain doses can affect to blood trygliceride levels. The objective of this study was to determine the effect of dietary high palm oil on tryglicerides level in wistar rat's blood. This research was an experimental study which applies post test only control group design. The samples were 12 male wistar rats that divided in to two groups. Control group which were administrated standard diet and treatment group which were administrated addition of 42,5\% palm oil to standar diet. After four weeks treatment, tryglicerides level were observed. The results showed that administration of dietary high palm oil effect on the increase of blood trygliceride levels. Blood trygliceride levels in treatment group was $165.6 \pm 19.527 \mathrm{mg} / \mathrm{dl}$ and the control group was $100.8 \pm 18.033 \mathrm{mg} / \mathrm{dl}$. There are significant difference between blood trygliceride levels treatment groups and control group $(p<0,05)$. The conclusion of this study is dietary high palm oil increased concentration of blood tryglicerides level.

Keywords: palm oil, blood trygliceride

Affiliasi penulis: 1. Pendidikan Dokter FK UNAND (Fakultas Kedokteran Universitas Andalas Padang), 2. Bagian Biokimia FK UNAND, 3. Bagian Biologi FK UNAND

Korespondensi: Aufa Azri Dany, Email: aufaazri@rocketmail.com, Telp: 085263969401

\section{PENDAHULUAN}

Trigliserida merupakan penyimpan lipid yang utama di dalam jaringan adiposa dan hati. Bentuk lipid ini akan terlepas setelah terjadi hidrolisis oleh enzim hormone sensitive lipase (HSL) menjadi asam lemak 
bebas dan gliserol sebagai sumber energi yang penting. Selain menjadi cadangan energi, trigliserida juga dikemas bersama lipoprotein dan fosfolipid dalam bentuk kilomikron yang kemudian beredar di sirkulasi darah. $^{1,2}$

Salah satu sumber trigliserida adalah melalui konsumsi minyak. Menurut Survei Sosial Ekonomi Nasional (SUSENAS) dalam BPS 2011 rata-rata konsumsi minyak mulai tahun 1998 hingga 2010 meningkat yaitu dari 205,9 kalori per kapita sehari hingga 233,39 kalori per kapita sehari. ${ }^{3}$ Di Sumatera Barat, $60 \%$ lemak yang dikonsumsi berasal dari lemak jenuh yang diperoleh dari produk kelapa dan minyak kelapa sawit. ${ }^{4}$

Minyak sawit dipilih dalam penelitian ini karena perbandingan komposisi asam lemak jenuh dan asam lemak tidak jenuhnya hampir sama, yaitu 50\% asam lemak jenuh (Saturated Fatty Acid atau SFA) dan kurang lebih $50 \%$ asam lemak tidak jenuh (Unsaturated Fatty Acid atau USFA) yang terdiri dari $40 \%$ asam lemak tidak jenuh dengan satu ikatan rangkap (Monounsaturated Fatty Acid atau MUFA) dan $10 \%$ asam lemak tidak jenuh dengan dua atau lebih ikatan rangkap (Polyunsaturated Fatty Acid atau PUFA). Minyak sawit juga mengandung tokoferol, tokotrienol dan karotenoid yang berfungsi sebagai antioksidan. ${ }^{5,6}$

Konsumsi Saturated Fatty Acid (SFA) yang berlebihan pada awalnya dapat dikembalikan menjadi normal dengan mengaktifkan proliferator-activated receptor- $\alpha$ (PPAR- $\alpha)$ sel hepatosit untuk oksidasi asam lemak dan PPAR-y sel adiposa untuk lipogenesis. Jika jumlah konsumsi SFA berlebihan dalam waktu lama menyebabkan hipertrofi dan hiperplasia jaringan adiposa yang kemudian memicu sekresi agen proinflamasi (TNF- $\alpha$ dan IL-10) dan resistensi insulin. Peningkatan TNF- $\alpha$ akan memicu lipolisis di jaringan adiposa sehingga akan meningkatkan asam lemak bebas di sirkulasi. ${ }^{7-9}$

Peningkatan asam lemak bebas di sirkulasi akan dikompensasi melalui lipogenesis de novo oleh sel hati, namun hal ini akan mengakibatkan peningkatan asam lemak bebas pada sel hati yang memicu penurunan aktivitas beta oksidasi. Ketidakseimbangan metabolisme asam lemak bebas akan memicu peningkatan biosintesis trigliserida $\mathrm{di}$ hati yang kemudian akan memicu kejadian non alcoholic fatty liver disease..$^{10,11,2}$

Amarapurkar et al tahun 2007, menyebutkan prevalensi NAFLD di Indonesia mencapai 30\% dan obesitas merupakan faktor risiko yang paling berkontribusi. ${ }^{12}$ Untuk menekan efek yang ditimbulkan oleh Saturated Fatty Acid (SFA) sebagai pemicu NAFLD, Unsaturated Fatty Acid (USFA) berperan menghambat sitokin inflamasi dan proses resistensi insulin sehingga mencegah terjadinya peningkatan asam lemak bebas di hati dan sirkulasi. USFA juga menginduksi peningkatan enzim CPT-1 yang akan meningkatkan aktivitas beta oksidasi di hati dengan merubah asam lemak bebas menjadi asetil KoA, sehingga terjadi penurunan proses esterifikasi asam lemak menjadi trigliserida. Efek yang diharapkan adalah kadar trigliserida di hati kembali normal dan menurunkan risiko perlemakan hati dan stress oksidatif. $^{13}$

Beberapa penelitian telah mengkaji mengenai pengaruh diet tinggi minyak sawit terhadap kadar trigliserida di dalam darah. Pada tahun 2011 Oluba et al menemukan penurunan kadar trigliserida pada tikus kontrol jika dibandingkan dengan tikus yang diberikan diet tinggi minyak sawit $5 \%$ selama 6 minggu. ${ }^{14}$ Hasil yang berbeda justru ditemukan oleh Mukherjee dan Mitra pada tahun 2011, kadar trigliserida pada tikus kontrol lebih meningkat jika dibandingkan dengan tikus yang diberikan diet tinggi minyak sawit $12 \%{ }^{15}$ Perbedaan ini mungkin salah satunya disebabkan oleh persentase minyak sawit yang digunakan.

Berdasarkan beberapa keterangan diatas, dapat disimpulkan bahwa komposisi asam lemak dari minyak sawit berperan meningkatkan atau menurunkan kadar trigliserida dalam mekanisme fatty liver sehingga perlu dilakukan penelitian yang memperlihatkan pengaruh pemberian diet tinggi minyak sawit terhadap kadar trigliserida darah.

\section{METODE}

Jenis penelitian ini adalah eksperimental dengan rancangan post test only control group design dengan satu kelompok kontrol yang diberikan diet standar dan satu kelompok perlakuan yang diberikan diet minyak sawit $50 \%$. Populasi dalam penelitian ini adalah tikus Wistar jantan dengan sampel sebanyak 
12 ekor ikus yang dipilih secara acak. Kriteria inklusinya yaitu tikus putih jantan galur Wistar (Rattus norvegicus), umur 2-3 bulan, berat badan 180-250 gram. Kriteria eksklusi adalah sampel dianggap drop out apabila selama penelitian dilaksanakan tikus putih jantan mati, sakit atau mengalami penurunan berat badan.

Analisis data dilakukan dengan menggunakan uji $t$-independent. Syarat untuk menggunakan uji $t$ independent adalah distribusi data harus normal. Apabila distribusi data tidak normal, dilakukan analisis data dengan uji Mann-Whitney. Analisis data bermakna apabila $p<0,05$.

\section{HASIL}

Penelitian ini telah dilaksanakan selama 4 minggu (28 hari) terhadap tikus jantan galur Wistar (Rattus norvegicus) dengan prosedur 6 ekor tikus sebagai kelompok control yang diberi diet standar, 6 ekor tikus sebagai kelompok perlakuan yang diberi diet minyak sawit 50\%. Kadar trigliserida darah yang diperiksa berasal dari 10 sampel darah karena terdapat dua sampel darah yang masuk kriteria eksklusi. Sampel yang diperiksa dari setiap kelompok dipilih masing-masing 5 sampel darah untuk menyeragamkan jumlah data setiap kelompok. Pemeriksaan trigliserida darah dilakukan dengan metode pengukuran GPO-PAP dengan alat ukur spektrofotometer digital tipe Photometer 5010 V5+.

Berikut adalah hasil yang diperoleh:

Tabel 1. Berat badan tikus wistar sebelum dan setelah perlakuan (gram)

\begin{tabular}{|c|c|c|c|c|c|}
\hline Tikus & & $\mathbf{n}$ & Min & Maks & Rerata \pm SD \\
\hline \multirow{2}{*}{ Kontrol } & sebelum & 5 & 196 & 234 & $221,4 \pm 15,25$ \\
\hline & setelah & 5 & 271 & 325 & $308,2 \pm 21,70$ \\
\hline \multirow{2}{*}{ Perlakuan } & sebelum & 5 & 204 & 255 & $223,2 \pm 19,75$ \\
\hline & setelah & 5 & 267 & 333 & $294,8 \pm 26,87$ \\
\hline
\end{tabular}

Tabel 2. Perbedaan rerata pertambahan berat badan tikus kontrol dan tikus perlakuan (gram)

\begin{tabular}{lcc}
\hline Tikus & Rerata \pm SD & p \\
\hline Kontrol & $86,8 \pm 8,32$ & 0,03 \\
\cline { 1 - 1 } Perlakuan & $71,6 \pm 9,81$ & \\
\hline
\end{tabular}

Tabel 3. Distribusi frekuensi kadar trigliserida darah tikus wistar $(\mathrm{mg} / \mathrm{dl})$

\begin{tabular}{lccclc}
\hline Tikus & $\mathbf{n}$ & Min & Maks & $\begin{array}{l}\text { Rerata } \pm \\
\text { SD }\end{array}$ & p \\
& & & & $100,8 \pm$ & \\
\hline Kontrol & 5 & 87 & 122 & 18,033 & 0,01 \\
& & & & $165,6 \pm$ & \\
Perlakuan & 5 & 140 & 189 & 19,527 & \\
& & & & &
\end{tabular}

Hasil uji normalitas dengan Shapiro-Wilk pada hasil pengukuran rerata pertambahan berat badan dan kadar trigliserida darah kedua kelompok tikus didapatkan nilai $p>0,05$, dan uji homegenity of variance didapatkan juga nilai $p>0,05$. Dari hasil tersebut dapat diambil kesimpulan bahwa distribusi kedua kelompok data adalah normal dan bisa dilakukan uji t-test independent.

Uji t-independent pada Tabel 2 didapatkan rerata pertambahan berat badan kelompok tikus kontrol lebih tinggi secara signifikan $(p<0,05)$ dibandingkan tikus perlakuan Rerata kadar trigliserida kelompok tikus perlakuan lebih tinggi secara signifikan $(p<0,05)$ dibandingkan kelompok tikus kontrol.

Kesimpulan hasil ini ialah rerata pertambahan berat badan tikus dan kadar trigliserida darah yang dibandingkan antara kedua kelompok terdapat perbedaan yang bermakna.

\section{PEMBAHASAN}

Berdasarkan hasil pada Tabel 1 dan Tabel 2 didapatkan rerata pertambahan berat badan pada tikus kontrol tikus kontrol sebesar 86,8 gram, tetapi pertambahan berat badan pada tikus perlakuan adalah sebesar 71,6 gram. Pada kelompok tikus kontrol didapatkan rerata pertambahan berat badan lebih tinggi secara signifikan dibandingkan rerata pertambahan berat badan pada tikus perlakuan $\mathrm{Hal}$ ini kemungkinan disebabkan komposisi asam lemak jenuh dan asam lemak tidak jenuh pada minyak sawit yang hampir sama sehingga tidak terlalu berpengaruh terhadap pertambahan berat badan. ${ }^{16}$

Pada Tabel 3 didapatkan rerata peningkatan kadar trigliserida pada tikus kontrol sebesar 100,8 $\mathrm{mg} / \mathrm{dl}$ sementara pada tikus perlakuan adalah sebesar $165,6 \mathrm{mg} / \mathrm{dl}$. Rerata kadar trigliserida kelompok tikus 
perlakuan lebih tinggi secara signifikan dibandingkan rerata kadar trigliserida kelompok kontrol.

Hipertrofi dan hiperplasia akan memicu sel sel inflamasi seperti TNF- $\alpha$, IL-6 dan MCP-1. Sel-sel inflamasi tersebut akan memicu aktifitas makrofag yang berefek pada peradangan pada jaringan adiposa. Sel-sel inflamasi juga akan memicu lipolisis pada jaringan adiposa sehingga akan meningkatkan asam lemak bebas didalam darah. Selanjutnya terjadilah mobilisasi FFA dari jaringan lemak menuju ke hepar dan berikatan dengan gliserol membentuk trigliserida. Semakin tinggi konsumsi lemak maka semakin tinggi pula sintesa trigliserida di hepar dan semakin tinggi kadar trigliserida dalam darah. ${ }^{17,18}$

Pada penelitian Mukherjee dan Mitra di tahun 2011, didapatkan juga peningkatan kadar trigliserida pada tikus kontrol dibandingkan dengan tikus yang diberikan diet tinggi minyak sawit $12 \%{ }^{15}$ Sementara sebaliknya Oluba et al di tahun 2011 justru menemukan kadar trigliserida pada tikus kontrol lebih rendah jika dibandingkan dengan tikus yang diberikan diet tinggi minyak sawit 5\% selama 6 minggu. ${ }^{14} \mathrm{Hal}$ ini bisa disebabkan karena dengan diet tinggi minyak sawit $5 \%$ maka sifat feedback negatif yang diharapkan dari USFA tidak cukup kuat untuk menekan efek yang ditimbulkan oleh konsumsi SFA, sehingga kemudian berakibat kepada penurunan proses $\beta$-oksidasi, peningkatan kejadian resistensi insulin dan lipolisis adiposa. Hal inilah yang mengakibatkan meningkatnya jumlah asam lemak bebas di sirkulasi yang beujung pada peningkatan biosintesis trigliserida. ${ }^{18}$

Penelitian Mukherjee dan Mitra dengan diet tinggi minyak sawit $12 \%$, kandungan USFA yaitu oleat dan linoleat yang lebih banyak dibandingkan dengan penelitian Oluba et al dapat memberikan efek feedback negatif terhadap SFA sehingga memperlambat proses akumulasi trigliserida di dalam darah.

Berbeda dengan hasil penelitian ini, diet tinggi minyak sawit $50 \%$ justru menyebabkan kadar SFA yang terlalu banyak dalam tubuh sehingga efek feedback negatif yang diharapkan dari USFA tidak cukup dominan untuk menekan atau memperlambat proses akumulasi trigliserida di dalam darah.

\section{KESIMPULAN}

Berdasarkan penelitian yang telah dilakukan, maka didapatkan kesimpulan bahwa rerata kadar trigliserida tikus perlakuan lebih tinggi secara signifikan dibanding tikus kontrol

\section{UCAPAN TERIMA KASIH}

Terima kasih kepada semua pihak yang telah banyak mengorbankan waktu, pikiran, dan tenaga dalam memberikan arahan dan masukan dalam penelitian ini.

\section{DAFTAR PUSTAKA}

1. Marks DB, Marks AD, Smith CM. Basic medical biochemistary: a clinical approach. Jakarta: EGC; 2000.

2. Murray AJ, Knight NS, Cochlin LE, McAleese S, Deacon Robert MJ, Nicholas J, et al. Deterioration of physical performance and cognitive function in rats with short-term high-fat feeding. The FASEB Journal. 2009; 23.

3. Badan Pusat Statistik. Rata-rata konsumsi kalori (kkal) per kapita sehari menurut kelompok makanan 1999, 2002-2011. (diunduh 18 April 2014). Tersedia dari: URL: HYPERLINK http://www.bps.go.id

4. Lipoeto NI. Zat gizi dan makanan pada penyakit kardiovaskular. Padang: Andalas University Press; 2006.

5. Kamsiah J, Aziz NS, Siew ST, Zahir IS. Changes in serum lipid profile and malondialdehyde following consumption of fresh or heated red palm oil. Medical Journal of Islamic Academy of Sciences. 2001;14(2):79-86.

6. Dauqan Eqbal MA, Sani HA, Abdullah A, Kasim ZM. Fatty acid composition of four different vegetable oil ( red palm olein, corn oil and coconut oil) by gas chromatography. $2^{\text {nd }}$ International Conference on Chemestry and Chemical Engineering IPCBEE. 2011; 14.

7. Slawik M, Vidal-Puig AJ. Lipotoxicity, overnutrition and energy metabolism in aging. Ageing Research Reviews. 2006;5:144-64. 
8. Guilherme A, Virbasilus JV, Purl V, Czech MP. Adipocyte dysfunctions linking obesity to insulin resistance and type 2 diabetes. Molecular Cell Biology. 2008; 9:367-77.

9. Kennedy A, Martinez K, Chuang C, Lapoint K, McIntosh M. Saturated fatty acid mediated inflammation and insulin resistant in adipose tissue, mechanism of action and implication. Journal of Nutrition - American Society for Nutrition.2009;139:1-4

10. Wei $Y$, Wang D, Pangliassotti M J. Saturated fatty acids promote endoplasmic reticulum stress and liver injury in rats with hepatic steatosis. Departement of Food Science and Human Nutrition, Colodro State University. Endocrinology. 2006;147(2):943-51.

11. Dowman JK, Tomlinson JW, Newsome PN. Pathogenesis of non alcoholic fatty liver disease. QJ Med.2010;103:71-83.

12. Amarapurkar DN, Estsuko $H$, Lesmana LA, Sollano JD, Pei Jer Chen, Khean Lee Goh. How common is non alcoholic fatty liver disease in the Asia-Pacific region and are there local differences. The Journal for the Asia-Pacific Working Party on NAFLD. 2007;10:1440-746.
13. Joung Hooh Ahn, Min HK, Hyung JK, Soo YC, Hyeok YK. Protective effect of oleic acid againts palmitic acid induced apoptosis in pancreatic ar42j cells and its mechanism. Korean $J$ Physiol Pharmacol. 2013;17:43-50.

14. Oluba OM, Eidangbe GO, Ojieh GC, Idonije BO. Palm and egusi melon oils lower serum and liver lipid profile and improve antioxidant activity in rats fed a high fat diet. Int. J. Med. Med. Sci. 201;3(2): 47-51.

15. Mukherje S, Mitra A. Health effect of palm oil. J Hum Ecol. 2009;26(3):197-203.

16. Kamsiah J, Aziz NS, Siew ST, Zahir IS. Changes in serum lipid profile and malondialdehyde following consumption of fres or heated red palm oil. Medical Journal of Islamic Academy of Science 14. $2001 ; 2: 79-86$.

17. Green A, Rumberger J M, Stuart C A, Ruhoff M S. Stimulation of Lipolysis Tumor Necrosis Factor-a in 3T3-L1 Adipocytes Is Glucose Dependent. Diabetes. 2004;53.

18. Tsalissavrina I, Wahono D, Handayani D. Pengaruh pemberian diet tinggi karbohidrat dibandingkan diet tinggi lemak terhadap kadar trigliserida dan HDL darah. Jurnal Kedokteran Brawijaya. 2006;22:80-9. 